\title{
A Comparison of Vitamin and Lutein Concentrations in Breast Milk from Four Asian Countries
}

\author{
My Tuyen Thi Nguyen ${ }^{1,2,+}$, Jieun Kim ${ }^{1, \dagger}{ }^{,}$Hyunjun Lee ${ }^{1}$, Soyoon Won ${ }^{1}$, Yongki Kim ${ }^{3}$, \\ Ji A. Jung ${ }^{3}$, Dan Li $\left.{ }^{4}{ }^{(}\right)$, Xuan Hong Mai To ${ }^{5}$, Khanh Trang Nguyen Huynh ${ }^{5}$, Thanh Van Le ${ }^{6}$, \\ Beenish Israr ${ }^{7}$, Hyun Joo An ${ }^{8}$ and Jaehan Kim ${ }^{1, * \mathbb{D}}$ \\ 1 Department of Food and Nutrition, Chungnam National University, Daejeon 34134, Korea; \\ mytuyen1108@gmail.com (M.T.T.N.); ai0107380@gmail.com (J.K.); dlguswns122@gmail.com (H.L.); \\ elementyoon@gmail.com (S.W.) \\ 2 College of Agriculture, Can Tho University, Can Tho City 900000, Vietnam \\ 3 Central Research Laboratory, Maeil Co., Ltd., 63 Jinwiseo-ro, Jinwi-myeon Pyeongtaek, \\ Gyeonggi-do 17706, Korea; kim6767@maeil.com (Y.K.); jungjia@maeil.com (J.A.J.) \\ 4 College of Food Science and Engineering, Changchun University, Changchun 130022, China; \\ drlidan@yahoo.com \\ 5 Department of Obstetrics and Gynecology, University of Medicine and Pharmacy at Ho Chi Minh City, \\ Ho Chi Minh City 700000, Vietnam; tomaixuanhong@ump.edu.vn (X.H.M.T.); \\ tranghnk08@gmail.com (K.T.N.H.) \\ 6 Faculty of Nursing and Medical Technology, University of Medicine and Pharmacy at Ho Chi Minh City, \\ Ho Chi Minh City 700000, Vietnam; thanhvan.vatlytrilieu@gmail.com \\ 7 Faculty of Food, Nutrition and Home Science, University of Agriculture, Faisalabad 38000, Pakistan; \\ beenish_israr@hotmail.com \\ 8 Graduate School of Analytical Science and Technology, Chungnam National University, \\ Daejeon 34134, Korea; hjan@cnu.ac.kr \\ * Correspondence: jaykim@cnu.ac.kr; Tel.: +82-042-821-6834 \\ + Both authors contributed equally.
}

Received: 29 April 2020; Accepted: 15 June 2020; Published: 17 June 2020

\begin{abstract}
Vitamins are the essential elements for human life and, particularly, for infant health Human milk is the best source of nutrients for newborns, however, the information of vitamins in Asian maternal milk is still limited. In this study, we have collected 580 Asian maternal milk samples from Korea $(n=254)$, China $(n=137)$, Pakistan $(n=92)$, and Vietnam $(n=97)$. The vitamin concentrations, including vitamin B-groups (8 vitamins), fat-soluble vitamin (retinol, D, E, K) and lutein in the breast milk of were investigated. The concentration of thiamin $\left(B_{1}\right)$, biotin $\left(B_{7}\right)$, and folic acid $\left(B_{9}\right)$ in mother's milk of four countries were not considerably different, while riboflavin $\left(B_{2}\right)$, pantothenic acid $\left(B_{5}\right)$, and pyridoxine $\left(B_{6}\right)$ level in Vietnam samples were significantly lower than those in other countries. In contrast, retinol (A) and tocopherol (E) were found to be higher levels in Vietnamese maternal milk. Korean and Chinese maternal milk had low concentrations of retinol that may cause vitamin A deficiency in children. However, Chinese mother's milk was distinguished with a high concentration of lutein. Pakistani mother's milk was observed as having a significant problem of folic acid $\left(B_{9}\right)$ deficiency. Regardless of the country, vitamin $B_{12}, K$, and D did not seem to be provided sufficiently through maternal milk. The moderate positive correlations were found between vitamin concentrations in each country and the pooled sample. The data obtained in this study were able to provide vital information to assess the nutritional status of breast milk in Asian countries and contributed to the efforts of ensuring the best nutrition for Asian children.
\end{abstract}

Keywords: human milk; quantification; vitamin; liquid-chromatography; mass spectrometry 


\section{Introduction}

In recent years, the attention to the concept of early-life metabolic programming and the future health of growing infants was remarkably rising. Early environmental factors, such as chemical exposure, diet, and nutritional supplements might have after-effects on human biology and long-term health. Human milk is recommended as the best source of nutrients for infants from 0 to 6 months $[1,2]$. It provides not only metabolic nutrients, but also functional elements such as vitamins, minerals, oligosaccharides, and various protective factors that could give long-term effects on physical, mental [3] and immune system development $[1,2,4,5]$.

Among these functional compounds, vitamins, particularly, have fundamental roles for the proper growth and development of infants. Vitamin A is one of the most important micronutrients affecting vision, the immune system, lung development, and maturation [6-8]. Vitamin D is involved in the calcium absorption, mineralization of the skeleton, and the prevention of rickets in children [9-12]. Vitamin E is a strong antioxidant that inhibits lipid peroxidation and protects cell membranes and lipoproteins from free radicals [8]. The water-soluble vitamin B complex is a co-enzyme of numerous biochemical reactions and has various functions in the human body [13-16]. In addition, lutein is a major carotenoid in the human eye [17]. It is also a dominant carotenoid in the infant's brain as well, and plays an important role in cognitive development [18].

It has been well noticed that the deficiency of vitamin or lutein could lead infants to improper development, diseases, and even cause death $[5,19,20]$. Vitamin deficiency of an infant occurs due to their limited amount of vitamin reserves at birth and the rapid consumption during their early age of growth. Since vitamin supplement depends only on the exogenous source, the amount of vitamins in human milk was essential for infant health and development. Moreover, the concentration of retinol in human milk is also used as a biomarker of vitamin A deficiency in lactating women and children up to 71 months [21].

The amount and types of vitamins and lutein in human milk are closely related to the mother's diet, nutritional status, and lactation duration [22,23]. Up to now, vitamin contents in breast milk were studied in several developed countries, however, the information about vitamin status in Asian mother's milk is still rare. Moreover, the different analytical methods contribute to the strong variation of vitamin content between countries. Here, we attempt to collect mother's milk from four Asian countries in different climate zones, including the temperate zone (Northeastern China), sub-tropical zone (South-Korea), and tropical zone (Vietnam and Pakistan). These mothers also consumed different styles of food, such as Muslim food in the Pakistan population and Asian cuisine for the others. Vitamin concentrations in human milk were studied and compared between countries.

\section{Materials and Methods}

\subsection{Sample Collection}

Human milk samples were collected from Korea, China, Pakistan, and Vietnam from 2017 to 2018. This study was approved by the Institutional Review Board of Chungnam National University (Korea), Maeil Dairies. Co., University of Medicine and Pharmacy at Ho Chi Minh City (Vietnam) and University of Agriculture (Faisalabad, Pakistan). Informed consent was obtained from all participants and methods were performed in accordance with the relevant guidelines and regulations. In this study, the number of human milk samples from Korea, China, Vietnam, and Pakistan were 254, 137, 92, and 97 samples, respectively.

Human milk was directly collected in a sterilized $50 \mathrm{~mL}$ conical tube (Corning, NY, USA), by hand press or breastmilk pump. The total volume of maternal milk donated from each mother was 50-150 mL. Then, the sample was delivered to the laboratory with a gel ice pack in well-insulated containers, to maintain a low temperature. The human milk sample was stored at $-80{ }^{\circ} \mathrm{C}$ before analysis. The sample was rejected from analysis if the storage time was longer than 2 months. 


\subsection{Materials}

Vitamin standards that include thiamin hydrochloride, riboflavin, nicotinic acid and nicotinamide, calcium-D-pantothenate, pyridoxin-hydrochloride, biotin, folic acid, cyanocobalamin and phylloquinone, were purchased from AccuStandard, New Haven, CT, USA. The following standards and reagents were obtained from Sigma-Aldrich, (Seoul, Korea): pyridoxal-hydrochloride $\left(B_{6}\right)$, all-trans retinol, all-trans tocopherol $(E)$, ergocalciferol $\left(D_{2}\right)$, cholecalciferol $\left(\mathrm{D}_{3}\right)$, all-trans lutein, butylated hydroxytoluene (BHT), HPLC grade solvent (methanol, ethanol, acetonitrile, and hexane). The HPLC grade MTBT (tert-Butyl methyl ether) was purchased from Thermo Fisher, Korea. Moreover, 7-dehydrocholesterol (DHC) was purchased from Cayman Chemical (MI, USA). Potassium hydroxide, ascorbic acid and sodium chloride were purchased from Deajung. Co. Ltd. (Busan, Korea).

\subsection{Water-Soluble Vitamin Analysis}

\subsubsection{Sample Preparation}

The milk sample $(0.5 \mathrm{~mL})$ was mixed with $1 \mathrm{~mL}$ of ethanol and sonicated for $20 \mathrm{~min}$. Then, $2 \mathrm{~mL}$ of hexane (containing $0.025 \%$ BHT) was added to the sample and shaken for $20 \mathrm{~min}$. The mixture was centrifuged $(3600 \times g, 15 \mathrm{~min})$. The aqueous layer was collected and mixed with $0.5 \mathrm{~mL}$ ice ethanol $\left(-80^{\circ} \mathrm{C}\right.$, $1 \mathrm{~h})$. The supernatant obtained after centrifugation $(21,000 \times \mathrm{g}, 20 \mathrm{~min})$ was quickly evaporated to remove ethanol. The sample was cleaned up by solid phase extraction using $\mathrm{C}_{18}$ cartridge (Sep-Pak $\mathrm{C}_{18}, 200 \mathrm{mg}$ sorbent, Waters, UK). The cartridge was activated and conditioned by methanol and distilled water. After sample loading, water-soluble vitamins were eluted by $6 \mathrm{~mL}$ of methanol: water (1:1). The elution was completely evaporated at $37^{\circ} \mathrm{C}$. The sample was reconstituted and diluted in acetonitrile: water (3:7) solution (containing $0.1 \%$ formic acid) before the injection into LC-MS/MS. The number of human milk samples in China, Korea, Pakistan and Vietnam were 111, 155, 97 and 92, respectively.

\subsubsection{LC-MS/MS Conditions}

Vitamin B-complexes were analyzed by using ultra performance liquid chromatography tandem mass spectrometry (6460 Triple Quadrupole System, Agilent, CA, USA). The analytical column was Glycan BEH Amide $\left(2.1 \times 100 \mathrm{~mm}, 0.35 \mathrm{~mm}\right.$, Waters, Hertfordshire, UK) and was kept at $30{ }^{\circ} \mathrm{C}$ during analysis. The solvents were $50 \%$ acetonitrile (solvent $\mathrm{A}$ ) and $90 \%$ acetonitrile (solvent $\mathrm{B}$ ), each of which contained $0.1 \%$ formic acid and $10 \mathrm{mM}$ ammonium formate. The flow rate was $0.3 \mathrm{~mL} / \mathrm{min}$ and the gradients between the time points were as follows: 0-2 $\mathrm{min}, \mathrm{B}=99.9 \%$; 2-6 $\mathrm{min}, \mathrm{B}=99.9-70 \% \mathrm{~B}$; 6-12 $\min \mathrm{B}=70-30 \% ; 12-14 \mathrm{~min}, \mathrm{~B}=30-10 \% ; 14-20 \mathrm{~min}, \mathrm{~B}=10 \% ; 21-30 \mathrm{~min}, \mathrm{~B}=99.9 \%$. The MS was performed in positive mode with the MS conditions, as follows: gas temperature, $300{ }^{\circ} \mathrm{C}$; gas flow, $8 \mathrm{~L} / \mathrm{min}$; nebulizer pressure, $45 \mathrm{psi}$; sheath gas temperature, $300^{\circ} \mathrm{C}$; sheath gas flow, $12 \mathrm{~L} / \mathrm{min}$; capillary voltage, $4000 \mathrm{~V}$ (positive); nozzle voltage, $1000 \mathrm{~V}$ (positive). The injection volume was $1 \mu \mathrm{L}$. The MS/MS parameter and MRM transitions of analytes are summarized in Table S1.

The standard curves were set up with the solution of thiamin, riboflavin, nicotinic acid, pyridoxine, pyridoxal ranged from 0.1 to $200 \mu \mathrm{g} / \mathrm{L}$. The standard solution of pantothenic acid, nicotinamide ranged from 50 to $5000 \mu \mathrm{g} / \mathrm{mL}$ and 0.1 to $500 \mu \mathrm{g} / \mathrm{mL}$, respectively. The $r^{2}$ of the standard curve for all standard materials ranged from 0.994 to 0.999 . The limit of quantitations (LOQ) for all vitamins were $0.1-0.6 \mathrm{ppb}$, except vitamin $\mathrm{B}_{9}(4.5 \mathrm{ppb})$ and $\mathrm{B}_{12}(1.8 \mathrm{ppb})$.

\subsection{Fat-Soluble Vitamins and Lutein Analysis}

\subsubsection{Samples Preparation}

The milk sample $(2 \mathrm{~mL})$ was put into a $15 \mathrm{~mL}$ centrifuge tube. Then, $4 \mathrm{~mL}$ of ethanol $(0.1 \%(w / v)$ $\mathrm{BHT}), 1 \mathrm{~mL}$ of $\mathrm{NaCl}$ solution $(2 \%, w / v), 1 \mathrm{~mL}$ of ascorbic acid solution $(4 \%)$ and $1 \mathrm{~mL}$ of $\mathrm{KOH}$ solution $(60 \%, w / v)$ were subsequently added. The mixture was saponification at $70{ }^{\circ} \mathrm{C}$ for $60 \mathrm{~min}$ in shaking water-bath. After that, sample was quickly cooled in ice water. The sample was double extracted in 
$5 \mathrm{~mL}$ hexane. Both hexane fractions were combined and washed with $\mathrm{NaCl}(0.1 \%)$ to remove $\mathrm{KOH}$. Then, hexane was evaporated under vacuum condition $\left(40{ }^{\circ} \mathrm{C}, 30 \mathrm{~min}\right)$. The residual was reconstituted in $100 \mu \mathrm{L}$ of isopropanol: hexane (75:25, 0.025\% BHT). The sample was filtrated through a $0.2 \mu \mathrm{m}$ and injected into HPLC.

\subsubsection{HPLC Conditions}

Fat-soluble vitamin was quantified by HPLC coupled with UV detector (1260 Agilent, California, USA). Analytes were separated using a C30 YMC Carotenoids column $(5 \mu \mathrm{m}, 4.6 \times 250 \mathrm{~mm}$, YMC Korea Co. ltd., Gyeonggi-do, Korea) at $30{ }^{\circ} \mathrm{C}$. The mobile phase A consisted of methanol: acetonitrile: water (4:5:1) and mobile phase B was methyl tert-butyl ether. The flow rate of the mobile phase was $1 \mathrm{~mL} / \mathrm{min}$. The gradient profile was as follows ( $t$ in min): $t_{0}, \mathrm{~B}=5 \% ; t_{20}, \mathrm{~B}=25 \% ; t_{25}$, $\mathrm{B}=40 \% ; t_{29}, \mathrm{~B}=70 \% ; t_{33}, \mathrm{~B}=90 \% ; t_{39}, \mathrm{~B}=90 \% ; t_{40}, \mathrm{~B}=5 \% ; t_{50}, \mathrm{~B}=5 \%$. Fat-soluble vitamins were detected at various wavelengths: retinol: $325 \mathrm{~nm}$, vitamin D: $265 \mathrm{~nm}$, vitamin E: $220 \mathrm{~nm}$, vitamin $\mathrm{K}_{1}$ : $246 \mathrm{~nm}$, and lutein: $445 \mathrm{~nm}$. The limit of quantitation (LOQ) of the method was 0.6-2.7 ppb for all fat-soluble vitamins, except vitamin E (10.5 ppb).

\subsection{Statistical Analysis}

The data were expressed as mean \pm standard deviation. The one-way ANOVA and Scheffe's multiple range test $(p<0.05)$ were used to define the significant difference between groups. The correlation between variables was determined by Pearson's product-moment correlation coefficient ( $r$-value). Stata/SE (version 12.1) has been used for the statistical analysis and the generation of resulting figures.

\section{Results}

\subsection{Variation of Vitamin Concentrations in Human Milk between Countries}

\subsubsection{Water-Soluble Vitamins}

The concentrations of water-soluble vitamin in human milk were diverse between and within the countries. In general, niacin (nicotinic acid + nicotinamide), pantothenic acid, retinol, and tocopherol were relatively abundant in human milk (0.4-0.6, 1.2-2.6, 0.3-0.8, 1.9-4.5 g/L, respectively). Thiamin, riboflavin, pyridoxine, biotin, phylloquinone, and lutein concentrations ranged from 1-150 $\mu \mathrm{g} / \mathrm{L}$ (Table 1). Not all the vitamin B complexes were found from human milk samples. Vitamin $B_{9}$ (folic acid) were observed $41.1 \%$ of Vietnamese mothers milk, meanwhile, only $2 \%$ of Pakistani mothers milk contained the folic acid above the LOQ $(4.5 \mu \mathrm{g} / \mathrm{L})$. Vitamin $\mathrm{B}_{12}$ occurred in a low quantity in human milk as well. Only $2-23 \%$ of samples in each country had vitamin B 12 higher than LOQ (1.8 $\mu \mathrm{g} / \mathrm{L})$. The average and the standard deviation in Table 1 were calculated using the values above the LOQ.

Table 1. Average of water soluble-vitamin concentration in human milk ( $\mu \mathrm{g} / \mathrm{L})$.

\begin{tabular}{|c|c|c|c|c|}
\hline & CHINA & KOREA & PAKISTAN & VIETNAM \\
\hline No. Sample & 111 & 155 & 97 & 92 \\
\hline Thiamin $\left(\mathrm{B}_{1}\right)$ & $68.1 \pm 51.2^{a, b}$ & $89.3 \pm 74.3^{b}$ & $66.5 \pm 93.7^{a, b}$ & $56.5 \pm 61.5^{a}$ \\
\hline Riboflavin $\left(\mathrm{B}_{2}\right)$ & $25.3 \pm 53.5^{\mathrm{a}}(82.9 \%)$ & $36.1 \pm 82.8^{\mathrm{a}, \mathrm{b}}(72.9 \%)$ & $58.0 \pm 43.3^{b}(100 \%)$ & $19.9 \pm 34.7^{\mathrm{a}}(77.8 \%)$ \\
\hline Niacin $\left(B_{3}\right)^{i}$ & $396.7 \pm 233.3^{a}$ & $393.7 \pm 278.3^{a}$ & $523.9 \pm 485.2^{a, b}$ & $553.8 \pm 440.2^{b}$ \\
\hline Pantothenic acid $\left(B_{5}\right)$ & $1924.0 \pm 2047.4^{\mathrm{a}, \mathrm{b}}$ & $2571.2 \pm 2932.2^{b}$ & $2557.4 \pm 2576.5^{b}$ & $1266.1 \pm 1242.7^{a}$ \\
\hline Pyridoxine $\left(\mathrm{B}_{6}\right)^{\mathrm{ii}}$ & $92.4 \pm 75.8^{a, b}$ & $115.1 \pm 137.3^{b}$ & $196.7 \pm 225.3^{c}$ & $56.4 \pm 60.4^{\mathrm{a}}$ \\
\hline Biotin $\left(B_{7}\right)$ & $12.1 \pm 9.0^{\mathrm{a}, \mathrm{b}}(95.5 \%)$ & $14.0 \pm 16.5^{\mathrm{b}}(92.9 \%)$ & $15.8 \pm 20.4^{\mathrm{b}}(100 \%)$ & $8.1 \pm 6.9^{\mathrm{a}}(87.8 \%)$ \\
\hline Folic acid $\left(B_{9}\right)$ & $32.3 \pm 13.1^{\mathrm{b}}(53.2 \%)$ & $58.6 \pm 35.5^{\mathrm{a}}(43.9 \%)$ & $31.5 \pm 1.3^{\mathrm{a}}(2 \%)$ & $40.2 \pm 19.8^{\mathrm{b}}(41.1 \%)$ \\
\hline Cyanocobalamin $\left(\mathrm{B}_{12}\right)$ & $4.9 \pm 1.1(13.5 \%)$ & $5.0 \pm 1.4(7.1 \%)$ & $2.7 \pm 4(25.8 \%)$ & $8.1 \pm 4.9(2.2 \%)$ \\
\hline
\end{tabular}

${ }^{i}$ Niacin = Nicotinic acid + Nicotinamide. ${ }^{\text {ii }}$ Pyridoxine $=$ Pyridoxal + Pyridoxine. Each value is expressed as mean \pm standard deviation. ${ }^{\mathrm{a}, \mathrm{b}}$ Means followed by the different letters in a row are significantly different at $p<0.05$ by Scheffe's multiple range test. Numbers in parentheses are the percentage of detected samples (concentration $>$ LOQ). 
Median and the total average that included the zero concentration $(<\mathrm{LOQ})$ were summarized in Supplementary Table S2. The comparison of vitamin concentration by country was described in both box plot and histogram (Figure 1). Regardless of countries, numerous outliners were obtained, showing a wide personal variation, even within the same country.
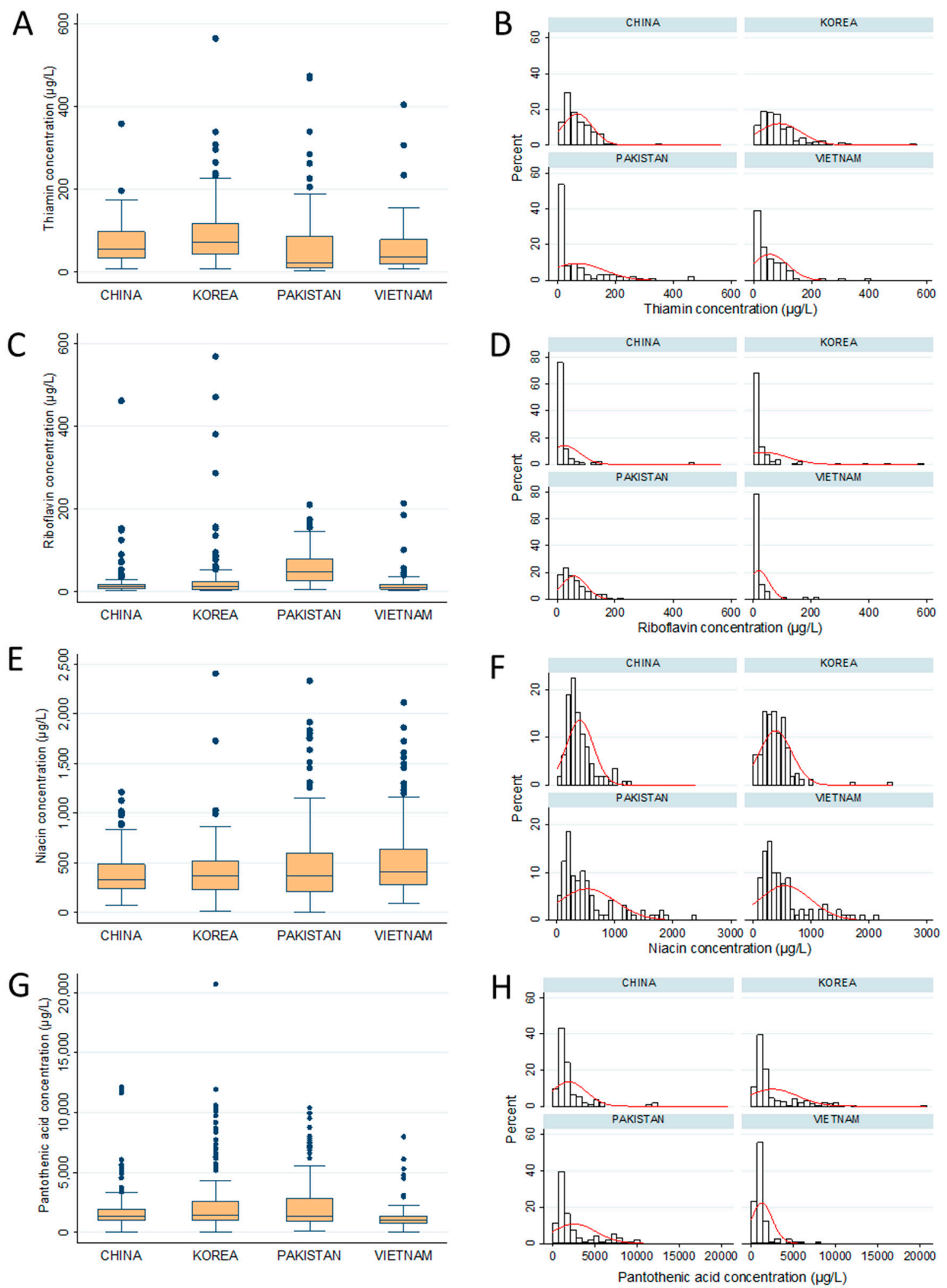

Figure 1. Cont. 

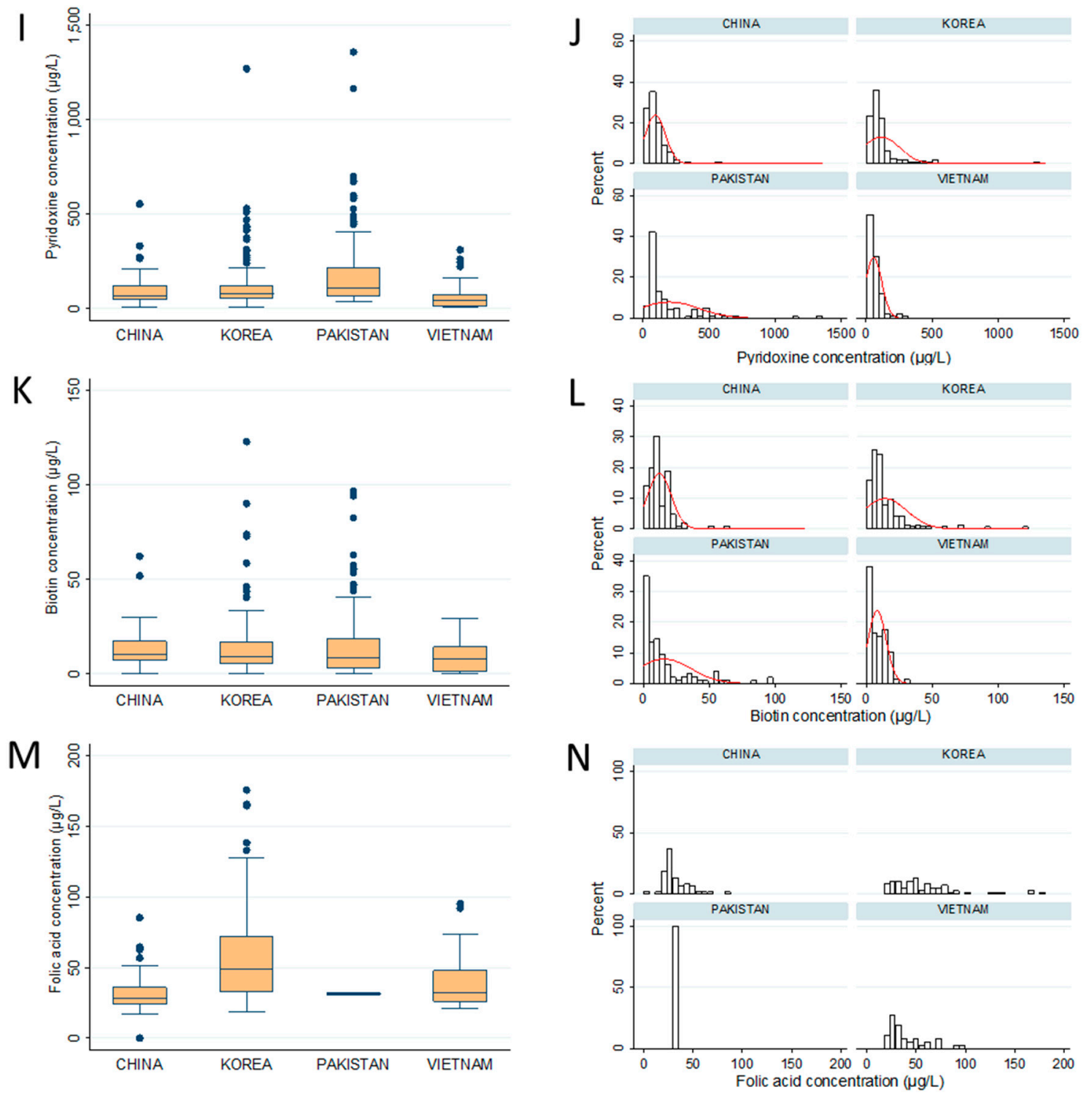

Figure 1. Distribution of water-soluble vitamins in mother's milk of the four countries by box plot and histograms. In the box plot, box indicates the first (Q1) and third (Q3) quartile, and the Whiskers indicate the $\pm 1.5 \times$ interquartile ranges from the box. The line in the box represent the media value. The red line in the histogram represents the normal distribution by computer simulation. (A,B): Thiamin; (C,D): Riboflavin; (E,F): Niacin: (G,H): Pantothenic acid; (I,J): Pyridoxine; (K,L): Biotin; $(\mathbf{M}, \mathbf{N})$ : Folic acid.

\section{- Thiamin (Vitamin B1)}

The average of free thiamin in Asian mother's milk ranged from 50 to $90 \mu \mathrm{g} / \mathrm{L}$. Chinese and Korean maternal milk exhibited less personal variation, whereas, around 55 and $40 \%$ of Pakistani and Vietnamese maternal milk had low thiamin content less than $20 \mu \mathrm{g} / \mathrm{L}$. A wide personal variation of thiamin in Pakistani maternal milk was observed, showing RSD of 140.9\% (Figure 1A,B).

\section{- Riboflavin (Vitamin $B_{2}$ )}

In this study, riboflavin was detected in $73 \%, 78 \%, 83 \%$, and $100 \%$ of human milk from Korea, Vietnam, China, and Pakistan, respectively (LOQ: $0.3 \mu \mathrm{g} / \mathrm{L}$ ). The average riboflavin concentrations were $20-60 \mu \mathrm{g} / \mathrm{L}$ (Table 1). Pakistani mother's milk had the highest concentration of riboflavin $(58.0 \pm 43.3 \mu \mathrm{g} / \mathrm{L})$, which were 1.6-3 times greater than in the maternal milk of other countries. 
Statistically, there was no significant difference in the average riboflavin content of Korean $(36.1 \pm 82.8 \mu \mathrm{g} / \mathrm{L})$, Chinese $(25.3 \pm 53.5 \mu \mathrm{g} / \mathrm{L})$, and Vietnamese $(19.9 \pm 34.7 \mu \mathrm{g} / \mathrm{L})$ maternal milk. However, numerous outliners were observed from the Korea, China, and Vietnam populations, which resulted in the strong variation of riboflavin concentration in human milk (Figure 1C,D).

- Niacin (Vitamin $B_{3}$ )

Niacin concentration was estimated by the sum of niacinamide and nicotinic acid content. Niacin levels in human milk from four Asian countries were similar (Figure 1E,F) and the medians were almost the same (Table S2). However, $15 \%(n=14)$ of samples in the Vietnam and Pakistan population had an extremely high niacin concentration over $1000 \mu \mathrm{g} / \mathrm{L}$. Subsequently, the average of niacin in Pakistani and Vietnamese maternal milks (523.9 \pm 485.2 and $553.8 \pm 440.2 \mu \mathrm{g} / \mathrm{L}$, respectively) seemed to be higher than those in Chinese and Korean maternal milk, which were about $400 \mu \mathrm{g} / \mathrm{L}$.

- Pantothenic acid (Vitamin $\mathrm{B}_{5}$ )

Pantothenic acid was the most abundant water-soluble vitamin, which ranged from 1200 to $2500 \mu \mathrm{g} / \mathrm{L}$. Vietnamese maternal milk had the lowest concentration of pantothenic acid, with only $1266.1 \pm 1242.7 \mu \mathrm{g} / \mathrm{L}$. It was nearly half of those in Korea and Pakistan, and lower than China. The pantothenic acid concentration in Asian maternal milk was widely spread from 0.01 to $15 \mathrm{~g} / \mathrm{L}$. Meanwhile, the Vietnam sample had a less personal variation, showing that $75 \%$ of samples were lower than $1.5 \mathrm{~g} / \mathrm{L}$ (Figure 1G,H).

- Pyridoxine (Vitamin $\mathrm{B}_{6}$ )

Pyridoxal is the predominant form of vitamin $\mathrm{B}_{6}$ in mother's milk. In this study, the pyridoxine content (vitamin $\mathrm{B}_{6}$ ) was calculated as total pyridoxine and pyridoxal concentration in milk. In Asian maternal milk, pyridoxine ranged from 56 to $200 \mu \mathrm{g} / \mathrm{L}$. There was no statistical significant difference among the average of pyridoxine content of Korean, Chinese, and Vietnamese mother's milk (Table 1). Meanwhile, the highest concentration of pyridoxine was found in Pakistani mother's milk $196.7 \pm 225.3 \mu \mathrm{g} / \mathrm{L}$ which was almost 4 times as many as those in Vietnam $(56.4 \mu \mathrm{g} / \mathrm{L})$. Around $20 \%$ of samples in the Pakistan population exhibited a high concentration from 300 up to $1500 \mu \mathrm{g} / \mathrm{L}$ (Figure 1I,J).

\section{- Biotin (Vitamin $B_{7}$ )}

The biotin concentrations in human milk were similar between four countries, however, a statistical difference has been found in their average concentrations. Biotin concentrations of Chinese, Korean, and Pakistani maternal milk were in the same range of 12.1-15.8 $\mu \mathrm{g} / \mathrm{L}$ with the high value outliers. Meanwhile, biotin in Vietnamese human milk was at a relatively low level $(8.1 \mu \mathrm{g} / \mathrm{L})$, without the high value outliers (Figure $1 \mathrm{~K}, \mathrm{~L}$ ).

- Folic acid (Vitamin $B_{9}$ )

In this study, only the free form of folic acid was quantified as a vitamin $\mathrm{B}_{9}$. Many human milks did not contain folic acid, in general. It has been found that only $40-60 \%$ of samples from each country have the $\mu \mathrm{g} / \mathrm{L}$ level of LOQ. Particularly, only $2 \%$ of Pakistani mother's milk contained folic acid above the quantitation limits. The concentration of folic acid in human milk, if presented, ranged from 30 to $60 \mu \mathrm{g} / \mathrm{L}$ (Figure 1M,N).

- Cyanocobalamin $\left(\mathrm{B}_{12}\right)$

Vitamin $B_{12}$ was found in human milk at a low quantity. Approximately, $25 \%$ of Pakistani mother's milk had cyanocobalamin above the LOQ (1.8 ppb), while it was only 2-13 percent in Korean, Chinese, and Vietnamese. The average concentrations ranged from 2 to $8 \mu \mathrm{g} / \mathrm{L}$ and were not significantly different between countries. 


\subsubsection{Fat-Soluble Vitamins}

Fat-soluble vitamins in human milk, including retinol, vitamin $\mathrm{D}, \mathrm{E}, \mathrm{K}$, and lutein, were quantified by UV-HPLC (Table 2). Vitamin E was the richest among fat-soluble vitamin, showing the concentration of $2-4 \mathrm{mg} / \mathrm{L}$. Retinol was the second abundant and occurred in human milk from 300-900 $\mu \mathrm{g} / \mathrm{L}$. Vitamin $\mathrm{D}$ concentration in all samples was under the limit of detection of our method (Vitamin $\mathrm{D}_{2}=0.5 \mathrm{ppb}$ and $\mathrm{D}_{3}=1 \mathrm{ppb}$ ). Only $40-70 \%$ of mother's milk in each country had vitamin $\mathrm{K}$ (phylloquinone) above the LOQ $(<2.7 \mathrm{ppb})$.

Table 2. Average of fat soluble-vitamin concentration in human milk $(\mu \mathrm{g} / \mathrm{L})$.

\begin{tabular}{|c|c|c|c|c|}
\hline & CHINA & KOREA & PAKISTAN & VIETNAM \\
\hline No. Sample & 137 & 254 & 97 & 92 \\
\hline Retinol (Vit A) & $364.5 \pm 232.7^{\mathrm{a}}$ & $356.5 \pm 180.1^{\mathrm{a}}$ & $622.1 \pm 447.3^{b}$ & $813.6 \pm 609.0^{c}$ \\
\hline Tocopherol (Vit E) & $1907.5 \pm 1309.1^{\mathrm{a}}$ & $2140.1 \pm 896.0^{a}$ & $3943.0 \pm 2874.5^{b}$ & $4413.4 \pm 5274.2^{b}$ \\
\hline Phylloquinone (Vit K) & $\begin{array}{c}19.3 \pm 16.7^{\mathrm{a}, \mathrm{b}} \\
(68.6 \%)\end{array}$ & $\begin{array}{c}18.9 \pm 18.5^{\mathrm{a}, \mathrm{b}} \\
(69.7 \%)\end{array}$ & $\begin{array}{c}25.7 \pm 17.2^{b} \\
(62.9 \%)\end{array}$ & $\begin{array}{c}12.9 \pm 13.9^{\mathrm{a}} \\
(43.5 \%)\end{array}$ \\
\hline Lutein & $66.1 \pm 51.6^{b}$ & $41.3 \pm 27.4^{\mathrm{a}}$ & $47.5 \pm 58.9^{a}$ & $49.7 \pm 47.9^{\mathrm{a}, \mathrm{b}}$ \\
\hline
\end{tabular}

${ }_{a, b}$ Means followed by the different letters in a row are significantly different at $p<0.05$ by Scheffe's multiple range test. Each value is expressed as a mean \pm standard deviation. Numbers in parentheses are the percentage of detected sample (concentration > LOQ). Phylloquinone concentration was calculated based on the detected sample only.

\section{- Retinol (Vitamin A)}

In human milk, retinol present in free and ester form together. In this study, retinyl esters were hydrolyzed to release free retinol by saponification before HPLC analysis. Total retinol concentration in Chinese and Korean maternal milk were similar together (350-360 $\mu \mathrm{g} / \mathrm{L})$, but significantly lower than that in Pakistani $(622.1 \pm 447.3 \mu \mathrm{g} / \mathrm{L})$ or Vietnamese $(813.6 \pm 609.0 \mu \mathrm{g} / \mathrm{L})$. Interestingly, retinol concentration in the Vietnamese mother's milk was 2.3 times higher than Korean and Chinese and exhibited strong personal variation. The distribution retinol in human milk of Korea and China were similar to normal distributions, although several high concentration outliers were observed (Figure 2A,B). Meanwhile, Pakistan and Vietnam data spread out widely from 70 to $2700 \mu \mathrm{g} / \mathrm{L}$, with the relative standard deviation (RSD) of $72-75 \%$.

- Tocopherol (Vitamin E)

Similar to retinol, the concentration of breast milk tocopherol in the four countries can be divided into two groups: low-narrow distribution (China and Korea) and high-wide distribution (Vietnam and Pakistan) (Figure 2C,D). The average of vitamin E in Pakistani and Vietnamese mother's milk were 3.9 and $4.4 \mathrm{~g} / \mathrm{L}$, respectively. China and Korea milk samples were $\sim 2 \mathrm{mg} / \mathrm{L}$, nearly half (40-50\%) of those in Pakistan or Vietnam.

- Phylloquinone (Vitamin K)

Phylloquinone presented as a low quantity in human milk, and varied from 0 to $97.4 \mu \mathrm{g} / \mathrm{L}$. About 60-70 percentage of Chinese, Korean, and Pakistani maternal milk had vitamin K more than $2.7 \mu \mathrm{g} / \mathrm{L}$ (LOQ). However, only $44 \%$ of the Vietnam population had phylloquinone concentration above LOQ. The average vitamin K concentration of Korea and China samples were 13-19 $\mu \mathrm{g} / \mathrm{L}$ with RSD of 86-97\%. Pakistani mother's milk contained $25.7 \pm 17.2 \mu \mathrm{g} / \mathrm{L}$ of phylloquinone, which was significantly greater than those in Vietnam $(12.9 \pm 13.9 \mu \mathrm{g} / \mathrm{L})$. The distributions of phylloquinone level in human milk were similar between four countries (Figure 2E,F). 
A

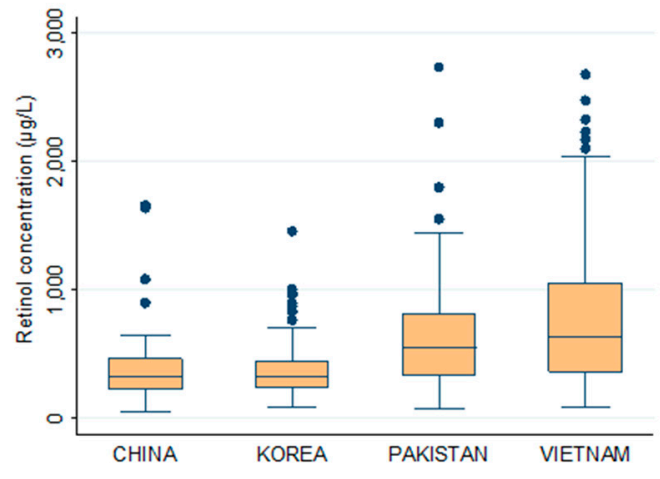

C

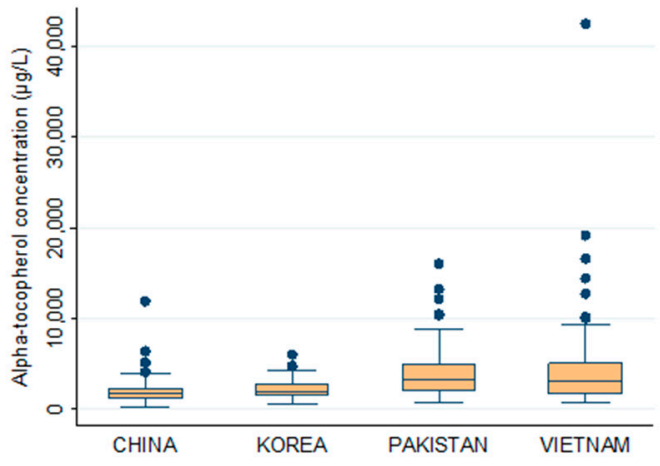

$\mathrm{E}$

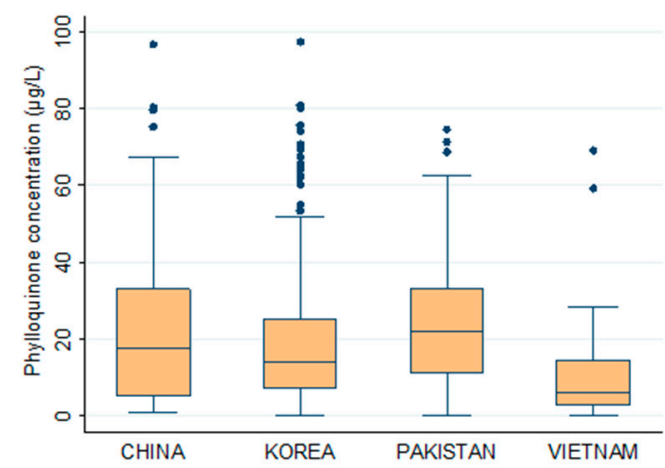

G

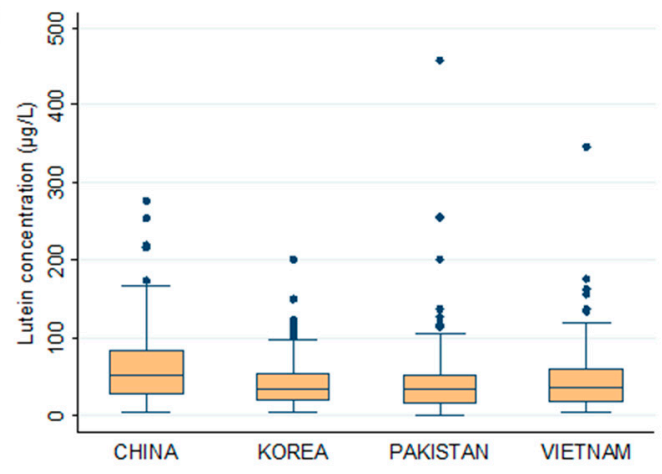

B

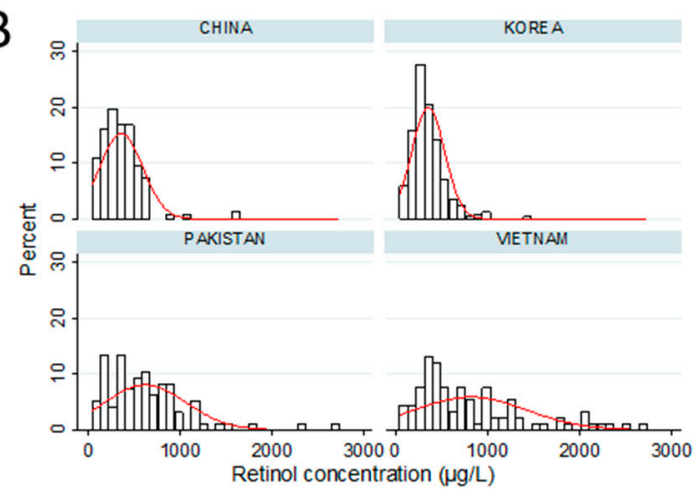

D

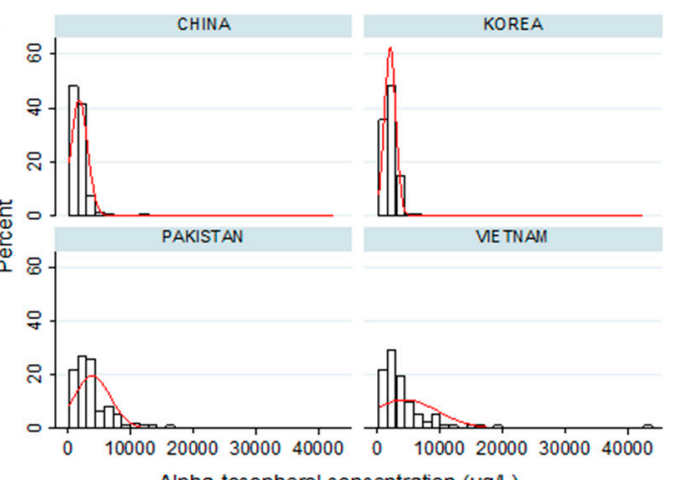

Alpha-tocopherol concentration $(\mu \mathrm{g} / \mathrm{L})$

$\mathrm{F}$

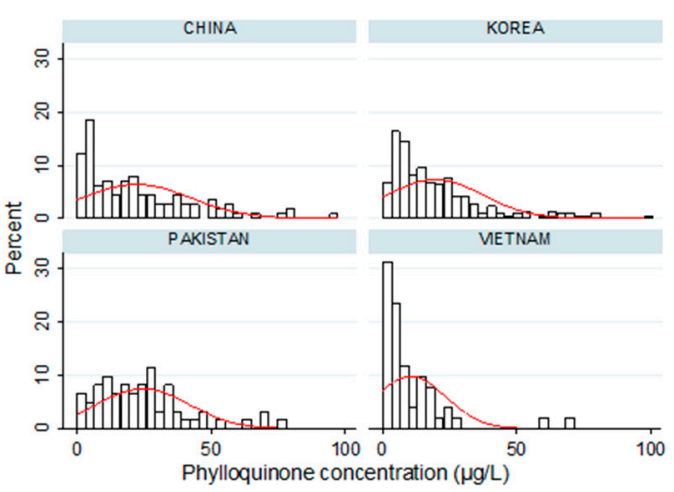

$\mathrm{H}$

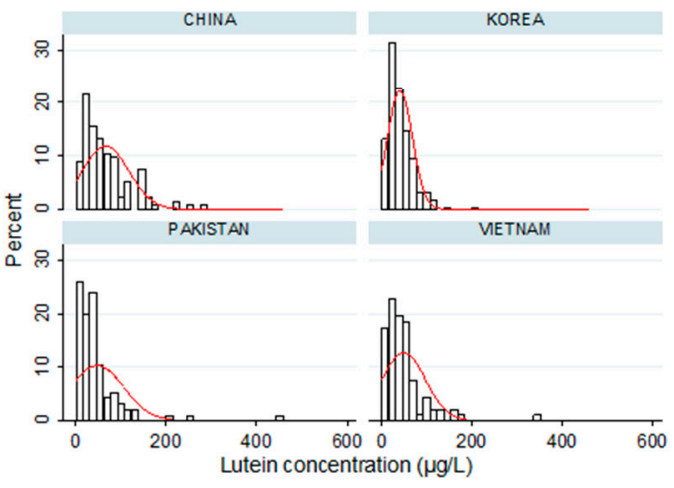

Figure 2. Distribution of fat soluble vitamin in mother's milk of the four Asia countries. In the box plot, box indicates the first $(\mathrm{Q} 1)$ and third $(\mathrm{Q} 3)$ quartile, and the Whiskers indicates the $\pm 1.5 \times$ interquartile ranges from the box. The line in the box represents the media value. The red line in the histogram represents the normal distribution by computer simulation (A,B): Retinol; (C,D): Apha-tocopherol; (E,F): Phylloquinone; (G,H): Lutein. 
- Lutein

Basically, the distribution patterns of lutein concentration in the breast milk of all four countries were similar (Figure 2G,H). The average lutein concentration in human milk did not significantly differ among the Korea, Pakistan, and Vietnam populations $(41.3,47.5$, and $49.7 \mu \mathrm{g} / \mathrm{L}$, respectively). It is noticed that the higher concentration of lutein was observed in Chinese maternal milk $(66.1 \mu \mathrm{g} / \mathrm{L})$.

- Vitamin D

Vitamin $\mathrm{D}$, including ergocalciferol (vitamin $\mathrm{D}_{2}$ ) and cholecalciferol (vitamin $\mathrm{D}_{3}$ ), was measured in human milk by UV-HPLC. The concentration of vitamin $\mathrm{D}_{2}$ and $\mathrm{D}_{3}$ in human milk of all four countries was lower than the limit of detection of $\mathrm{D}_{2}=0.5 \mu \mathrm{g} / \mathrm{L}$ and $\mathrm{D}_{3}=1 \mu \mathrm{g} / \mathrm{L}$. However, cholesterol, which is the precursor of vitamin $\mathrm{D}_{3}$, was detected in human milk at the level of 90-175 mg/L. Moreover, desmosterol, a precursor of cholesterol, was also observed in human milk, with the concentration ranging from $10-13 \mathrm{mg} / \mathrm{L}$.

\subsection{Correlation between Vitamins and Lutein}

Pearson's correlations between vitamins in the pooled sample were illustrated in Table 3. Most of the correlation coefficients are low $(<0.5)$. There were several moderate positive correlations observed, including pyridoxine $\left(B_{6}\right)$ versus thiamin $\left(B_{1}\right)$ and pantothenic acid $\left(B_{5}\right)(r=0.450,0.464)$; retinol versus tocopherol (0.497).

Table 3. Correlation coefficients between vitamin concentrations in the pooled sample $(n=452)$.

\begin{tabular}{ccccccccccccc}
\hline & $\mathbf{B}_{\mathbf{1}}$ & $\mathbf{B}_{\mathbf{2}}$ & $\mathbf{B}_{\mathbf{3}}$ & $\mathbf{B}_{\mathbf{5}}$ & $\mathbf{B}_{\mathbf{6}}$ & $\mathbf{B}_{\mathbf{7}}$ & $\mathbf{B}_{\mathbf{9}}$ & $\mathbf{B}_{\mathbf{1 2}}$ & Retinol & $\mathbf{E}$ & $\mathbf{K}$ & Lutein \\
\hline $\mathbf{B}_{\mathbf{1}}$ & 1.000 & & & & & & & & & & & \\
$\mathbf{B}_{\mathbf{2}}$ & 0.074 & 1.000 & & & & & & & & & \\
$\mathbf{B}_{\mathbf{3}}$ & 0.318 & 0.083 & 1.000 & & & & & & & & \\
$\mathbf{B}_{\mathbf{5}}$ & 0.342 & 0.181 & 0.351 & 1.000 & & & & & & & \\
$\mathbf{B}_{\mathbf{6}}$ & 0.450 & 0.362 & 0.208 & 0.464 & 1.000 & & & & & & \\
$\mathbf{B}_{\mathbf{7}}$ & 0.137 & 0.399 & 0.118 & 0.228 & 0.207 & 1.000 & & & & & \\
$\mathbf{B}_{\mathbf{9}}$ & 0.171 & 0.115 & 0.106 & 0.340 & 0.165 & 0.253 & 1.000 & & & & & \\
$\mathbf{B}_{\mathbf{1 2}}$ & 0.102 & 0.098 & 0.009 & 0.029 & 0.007 & 0.005 & -0.005 & 1.000 & & & & \\
Retinol & -0.164 & 0.012 & 0.056 & -0.068 & -0.076 & -0.079 & -0.091 & -0.016 & 1.000 & & & \\
$\mathbf{E}$ & -0.168 & 0.042 & -0.063 & -0.109 & -0.076 & -0.022 & -0.089 & -0.010 & 0.497 & 1.000 & & \\
$\mathbf{K}$ & 0.009 & 0.080 & -0.026 & -0.034 & -0.002 & 0.067 & -0.013 & -0.049 & -0.065 & -0.025 & 1.000 & \\
Lutein & -0.118 & -0.039 & -0.032 & -0.055 & -0.084 & -0.033 & -0.076 & -0.095 & 0.351 & 0.388 & 0.081 & 1.000 \\
\hline
\end{tabular}

In the comparison of each individual country, the correlations between components were quite random and the similarity was not found among four countries. However, there were several common features: correlation is found among vitamin B together or fat-soluble vitamins together. Positive correlations were observed such as vitamin $B_{6}$ versus vitamin $B_{5}$ in China, Pakistan and Vietnam $(r=0.61,0.631,0.479)$; vitamin $\mathrm{B}_{6}$ versus vitamin $\mathrm{B}_{2}$ in China, Korea, and Vietnam $(r=0.704,0.479$, $0.604)$; retinol versus vitamin $\mathrm{E}$ in China and Pakistan $(r=0.461 ; 0.795)$. Other specific correlations in each country could be seen in Tables S3-S6.

\section{Discussion}

Vitamins belong to micronutrients and are essential for infant growth and development. Breast milk contains almost all the vitamins that a healthy full-term baby needs, although the supplementation of vitamin $\mathrm{D}$ and $\mathrm{K}$ is still recommended for infants. However, not all babies can be breastfed, for various reasons, which makes infant formula inevitable. To supply sufficient and balanced vitamins for infant's needs, the reference information of vitamin concentration in human milk is necessitated for infant formula setting up.

Vitamin concentrations in breast milk were not consistent widely in many publications. It is partly due to the complex structures and isomers of vitamins and the subsequent diversity of the 
numbers and types of vitamin standards. Vitamin B occurs in human milk under various forms and derivatives. It was reported that vitamin $B_{1}$ is present in human milk under the forms of free thiamin, thiamin-monophosphate, and thiamin-pyrophosphate. Similarly, vitamin $\mathrm{B}_{2}$ was founded as free riboflavin and flavin adenine-dinucleotide [19], or vitamin $B_{3}$ naturally presented as nicotinic acid and nicotinamide in human milk. Vitamin $\mathrm{B}_{6}$ mainly occurs as pyridoxal and a small amount of pyridoxine + pyridoxamine [24]. Vitamin $\mathrm{B}_{9}$ in human milk consisted of unmetabolized folic acid (23\%), 5-methyl-tetrahydrofolate (55\%), and other reduced folates (tetrahydrofolate (THF), 5-formyl-THF and 5, 10-methenyl-THF) [25], and so on. In the same way, the fat-soluble vitamin also had various forms and isomers, such as vitamin $\mathrm{E}$ (alpha, beta, and gamma-tocopherol), vitamin $\mathrm{K}$ (phylloquinone, menaquinones) [26], vitamin D metabolites [21], cis and trans-lutein isomer [27].

In this study, thiamin (free form), riboflavin (free form), niacin (nicotinamide and nicotinic acid), D-pantothenic acid, vitamin $\mathrm{B}_{6}$ (pyridoxal and pyridoxine), biotin, folic acid (free form) and cyanocobalamin were analyzed. Although the concentrations of all vitamin metabolites were not able to be covered in one study, we attempt to make a comparison of our human milk vitamin data obtain from four Asian countries and previously published data of the same metabolites (Table 4). Apparently, each vitamin concentration found from various studies varied in the wide range. On the other hand, the level of vitamin obtained in this study was reasonable and within a similar range of previous studies. In this study, human milk was randomly collected during the lactation stage, from both supplementation users and non-users. Vitamin $\mathrm{K}$ value in this study was quite high, however, it should be noted that the value was only calculated from the sample observed the vitamin $\mathrm{K}(\mathrm{LOQ}=2.7 \mu \mathrm{g} / \mathrm{L})$. There was 30 to $54 \%$ of mother's milk in which vitamin K was not found. Taking these samples into consideration, the concentration of vitamin $\mathrm{K}$ in Asian human milk became $12.6 \pm 17.0 \mu \mathrm{g} / \mathrm{L}$ (median: $6.0 \mu \mathrm{g} / \mathrm{L})$.

Although we could not cover all of the vitamins, a general comparison of vitamin concentration in human milk between Asian countries would be valuable. The vitamin B level in the Vietnamese population was usually significantly lower than those in breast milk from other countries, particularly, riboflavin $\left(B_{2}\right)$, pantothenic acid $\left(B_{5}\right)$, and pyridoxine $\left(B_{6}\right)$. Pakistani maternal milk was noticed with a low concentration of folic acid. It was reported that thiamin, riboflavin, and pyridoxine in the mother were also strongly influenced by the mother's diet or supplementation $[15,28]$. Hence, a recommendation of supplementation or improving vitamin B in the diet seems to be required for Vietnamese and Pakistani mothers.

Breastmilk is a great source of lutein for infants. The lutein concentration in breastmilk may vary from 10 to $100 \mu \mathrm{g} / \mathrm{L}$, which is several times higher than that in cow milk (approximate 5-15 $\mu \mathrm{g} / \mathrm{L}$ ) [29]. Particularly, lutein originating from breast milk plays an important role in visual processing in early life [30]. It is the predominant carotenoid in adults and infant brains [31], especially in the neocortex area, and also a key functional component in the neural retina [32]. Recently, research on rhesus macaques indicated that lutein supplementation of infant formula significantly increased serum and tissue lutein concentrations compared to the unsupplemented formula, however, both of them were still lower than those in breastfed infants.

Interestingly, lutein in Chinese maternal milk was higher than in other countries. The average of lutein concentrations in human milk from Korean, Pakistani, and Vietnamese mothers was 40-50 $\mu \mathrm{g} / \mathrm{L}$ while $66.1 \mu \mathrm{g} / \mathrm{L}$ in Chinese maternal milk. It was also observed that lutein in China maternal milk had a high content, up to the median of $93.1 \mu \mathrm{g} / \mathrm{L}$ [33]. It might be due to the difference in the mother's diet, since the breast milk lutein concentration depended on maternal intake [34]. 
Table 4. Vitamins and lutein concentration $(\mu \mathrm{g} / \mathrm{L})$ reported in human milk.

\begin{tabular}{|c|c|c|c|c|c|c|c|}
\hline Vitamin & Country & Analysis Method & $n$ & Median & Mean & SD & Ref. \\
\hline \multicolumn{8}{|c|}{ Thiamin (Vit. $\mathbf{B}_{1}$ ) } \\
\hline & China & UPLC-MS/MS & 6419 & $5.0-40.7$ & \multirow{5}{*}{123} & \multirow{5}{*}{32} & [24] \\
\hline & Japan & HPLC-FID & 691 & & & & [35] \\
\hline & China & HPLC-MS/MS & 443 & $31.3-62.8$ & & & [36] \\
\hline & Malawian & HPLC-FLD & 177 & $10.5-40.9$ & & & [19] \\
\hline & Bangladesh & HPLC-FLD & 18 & 116 & & & [28] \\
\hline \multicolumn{8}{|c|}{ Riboflavin (Vit. $\mathbf{B}_{2}$ ) } \\
\hline & China & UPLC-MS/MS & 6419 & $29.3-40.6$ & & & [24] \\
\hline & China & HPLC-MS/MS & 443 & 119-208 & & & [36] \\
\hline & Malawian & ULPC-MS/MS & 177 & $6.3-7.3$ & & & [19] \\
\hline & Bangladesh & HPLC-MS/MS & 18 & 24 & & & [28] \\
\hline \multicolumn{8}{|c|}{ Niacin (Vit. $\mathbf{B}_{3}$ ) } \\
\hline & China & UPLC-MS/MS & 6419 & $470.7-687.0$ & \multirow{4}{*}{329} & \multirow{4}{*}{204} & [24] \\
\hline & Japan & HPLC-UV & 619 & & & & [35] \\
\hline & China & HPLC-MS/MS & 443 & $1940-3000$ & & & [36] \\
\hline & Bangladesh & HPLC-MS/MS & 18 & 219 & & & [28] \\
\hline \multicolumn{8}{|c|}{ Pantothenic acid (Vit. $B_{5}$ ) } \\
\hline & China & UPLC-MS/MS & 6419 & $1770.9-2626.8$ & \multirow{3}{*}{2700} & \multirow{3}{*}{900} & [24] \\
\hline & Japan & Microbiological assay & 619 & & & & [35] \\
\hline & China & HPLC-MS/MS & 443 & $1790-2910$ & & & [36] \\
\hline \multicolumn{8}{|c|}{ Pyridoxine (Vit. $B_{6}$ ) } \\
\hline & China & UPLC-MS/MS & 6419 & $4.6-80.7$ & \multirow{4}{*}{57} & \multirow{4}{*}{25} & [24] \\
\hline & Japan & Microbiological assay & 619 & & & & [35] \\
\hline & China & HPLC-MS/MS & 443 & $63.4-102.0$ & & & [36] \\
\hline & Bangladesh & HPLC-MS/MS & 18 & 81 & & & [28] \\
\hline \multicolumn{8}{|c|}{ Biotin (Vit. $\mathbf{B}_{7}$ ) } \\
\hline & Japan & Microbiological & 619 & & 5.0 & 2.3 & [35] \\
\hline & China & HPLC-MS/MS & 443 & $4.6-6.1$ & & & [36] \\
\hline \multicolumn{8}{|c|}{ Folic acid (Vit. $\left.B_{9}\right)$} \\
\hline & Japan & HPLC-FID & 619 & & 62 & 29 & [35] \\
\hline & China & HPLC-MS/MS & 443 & $7.3-24.4$ & & & [36] \\
\hline & Canada & HPLC-MS/MS & 160 & & 20.7 & 0.7 & [25] \\
\hline \multicolumn{8}{|c|}{ Cyanocobalamin (Vit. $B_{12}$ ) } \\
\hline & Japan & Microbiological assay & 619 & & 0.4 & 0.2 & [35] \\
\hline & Bangladesh & $\begin{array}{c}\text { Quantitative } \\
\text { immuno-analyzer }\end{array}$ & 18 & 0.175 & & & [28] \\
\hline & India & $\begin{array}{c}\text { Competitive protein } \\
\text { binding immunoassay }\end{array}$ & 326 & $0.9-1.8$ & & & [37] \\
\hline \multicolumn{8}{|c|}{ Retinol (Vit. A) } \\
\hline & Japan & HPLC-FID & 82 & & 455 & 264 & [38] \\
\hline & Bangladesh & HPLC & 18 & 391 & & & [28] \\
\hline & Korea & HPLC-UV & 334 & & 395.8 & 196.4 & [39] \\
\hline & Brazil & HPLC-UV & 103 & & 624.6 & 229.2 & [40] \\
\hline & Brazil & HPLC-UV & 136 & & 483.3 & 197.3 & [41] \\
\hline \multicolumn{8}{|c|}{ Tocopherol (Vit. E) } \\
\hline & Japan & HPLC-FID & 619 & & 3250 & 1650 & [35] \\
\hline & Japan & HPLC & 82 & & 5087 & 5042 & [38] \\
\hline & Bangladesh & HPLC & 18 & 4400 & & & [28] \\
\hline & Korea & HPLC-UV & 334 & & 230 & 130 & [39] \\
\hline & Brazil & HPLC-UV & 103 & & $11,241.5$ & 5513 & [40] \\
\hline & & Choleca & erol $(V$ & $\left.D_{3}\right)$ & & & \\
\hline & Japanese & HPLC-UV & 114 & & 0.08 & & [35] \\
\hline & Japanese & LC-MS/MS & 88 & & 0.088 & & [38] \\
\hline & USA & LC-MS/MS & 40 & & $0.008-0.04$ & & [42] \\
\hline & Denmark & $\begin{array}{c}\text { LC-MS/MS } \\
\text { (LOD: } 0.2 \mathrm{nmol})\end{array}$ & 120 & & $\begin{array}{c}0.11-0.57 \\
(27-46 \%<\mathrm{LOD})\end{array}$ & & [43] \\
\hline
\end{tabular}


Table 4. Cont.

\begin{tabular}{|c|c|c|c|c|c|c|c|}
\hline Vitamin & Country & Analysis Method & $n$ & Median & Mean & SD & Ref. \\
\hline \multicolumn{8}{|c|}{ Phylloquinone (Vit. K) } \\
\hline & Japan & HPLC-MS/MS & 82 & \multirow{6}{*}{$0.9-1.2$} & 3.7 & 2.2 & [38] \\
\hline \multirow{2}{*}{\multicolumn{2}{|c|}{ Japan }} & HPLC-FID & & & 4.3 & 2.9 & [44] \\
\hline & & HPLC-FID & & & & & [45] \\
\hline \multirow{3}{*}{\multicolumn{2}{|c|}{ UK }} & HPLC-MS/MS & 29 & & $2.1-140$ & & [46] \\
\hline & & & 15 & & $2.87-3.39$ & & [47] \\
\hline & & & & & $1.1-130$ & & [48] \\
\hline \multicolumn{8}{|c|}{ Lutein } \\
\hline & Mexico & HPLC-UV & 20 & & 27.3 & 11.8 & [49] \\
\hline & Japan & HPLC-UV & 20 & & 29.1 & 21.3 & [49] \\
\hline & UK & HPLC-UV & 20 & & 12.4 & 7.8 & [49] \\
\hline & China & HPLC-UV & 20 & 93.1 & & & [33] \\
\hline & USA & HPLC-UV & 20 & 41.7 & & & [33] \\
\hline & Mexico & HPLC-UV & 20 & 39.2 & & & [33] \\
\hline & Italy & HPLC-UV & 15 & & 62.6 & 28.4 & [34] \\
\hline & China & HPLC-UV & 509 & $22-58$ & & & [50] \\
\hline
\end{tabular}

The value was converted to the same unit $(\mu \mathrm{g} / \mathrm{L})$.

Based on the data we observed, it was still difficult to conclude whether the human milk of Asian mothers could provide enough vitamin for their baby or not. However, the data in this study also clearly indicates that vitamins $B_{12}, K$, and D were not sufficient in human milk. Vitamin $\mathrm{K}$ intake for the first 0-6 months is recommended at $5 \mathrm{mg} /$ day [51]. Based on the obtained data, approximately $43-53 \%$ of infants in Korea, China, and Pakistan and $75 \%$ of Vietnam did not get enough vitamin K. Vitamin $B_{12}$ and D levels of other countries were also reported as low as the range of pmol/L [35,43].

Under the circumstances, providing additional vitamin $B_{12}$ and $D$ through the mother's diet or supplements seems to be necessary. It was reported that $B_{12}$ supplementation of the mother during pregnancy and early lactation could improve vitamin $B_{12}$ status in breast milk and infant [37]. Moreover, the mother supplemented with a high dose of vitamin D was able to increase a slight amount of vitamin D in her breast milk [43,52]. In this regard, the WHO strongly recommended giving vitamin supplementation for breastfed infants [51]. It is recommended that they supplement with $400 \mathrm{IU}$ per day of vitamin D, beginning in the first few days of life [53]. Additionally, it has been recommended that mothers should pay more attention to their diets or provide vitamin $\mathrm{K}$ supplementation to their baby [51].

Vitamin A deficiency is one of the most common health problems in the world. In addition, retinol concentration of mother's milk of less than $1.05 \mu \mathrm{mol} / \mathrm{L}$ is used as a biomarker of vitamin A deficiency (VAD) in lactating women and children up to 71 months [51]. The percentage of the indicator (milk retinol $<1.05 \mu \mathrm{mol} / \mathrm{L}) \geq 25 \%$, from 10 to $25 \%$, or $<10 \%$, is considered as severe, moderate, and mild VAD, respectively [51]. Interestingly, retinol in Vietnamese maternal milk was richer than in other countries. The Korean and Chinese populations had a high percentage of milk retinol $<1.05 \mu \mathrm{mol} / \mathrm{L}$, with $44 \%$, followed by Pakistan (23\%) and Vietnam (16\%). These data indicated that Korea and China mother and infant are at high risk of VAD.

A comprehensive comparison of fat and water-soluble vitamins in breast milk between countries has been carried out in this work. The data exhibited a general view of vitamin status in Asian maternal milk. It could provide useful information for mother and baby care that may be used as a reference to establish the best infant formula for Asian babies.

Supplementary Materials: The following are available online at http://www.mdpi.com/2072-6643/12/6/1794/s1, Table S1. The quantification channels of the analytes and the parameters used for their quantification. Table S2. The average and median of water soluble-vitamin concentration in human milk $(\mu \mathrm{g} / \mathrm{L})$. Table S3. Correlation coefficients between vitamin concentrations in China sample $(n=111)$. Table S4. Correlation coefficients between vitamin concentrations in Korea sample $(n=155)$. Table S5. Correlation coefficients between vitamin concentrations in Pakistan sample $(n=97)$. Table S6. Correlation coefficients between vitamin concentrations in Vietnam sample $(n=90)$. 
Author Contributions: Conceptualization, supervision, project administration, J.K. (Jaehan Kim); methodology, M.T.T.N.; formal analysis, M.T.T.N., J.K. (Jieun Kim), H.L., S.W.; resources, D.L., X.H.M.T., K.T.N.H., T.V.L., B.I.; H.J.A.; writing—original draft preparation, J.K. (Jaehan Kim), M.T.T.N; funding acquisition, Y.K., J.A.J. All authors have read and agreed to the published version of the manuscript.

Funding: This research was supported by Maeil Dairies Co., Ltd., and the National Research Foundation of Korea (NRF) grant funded by the Korean government (MSIT) (2020R1A2C1011944).

Acknowledgments: We thank Maeil Dairies Co., Ltd. for their financial and enthusiastic support. We gratefully acknowledge the contributions of colleagues in the Nutritional Food Microbiology Laboratory, Department of Food and Nutrition, Chungnam National University, Korea.

Conflicts of Interest: The authors declare no conflict of interest.

\section{References}

1. Jackson, K.M.; Nazar, A.M. Breastfeeding, the immune response, and long-term health. J. Am. Osteopat. Assoc. 2006, 106, 203-207.

2. Martin, C.R.; Ling, P.-R.; Blackburn, G.L. Review of infant feeding: Key features of breast milk and infant formula. Nutrients 2016, 8, 279. [CrossRef] [PubMed]

3. Walfisch, A.; Sermer, C.; Cressman, A.; Koren, G. Breast milk and cognitive development-The role of confounders: A systematic review. BMJ Open 2013, 3, e003259. [CrossRef] [PubMed]

4. Souza, G.; Dolinsky, M.; Matos, A.; Chagas, C.; Ramalho, A. Vitamin A concentration in human milk and its relationship with liver reserve formation and compliance with the recommended daily intake of vitamin A in pre-term and term infants in exclusive breastfeeding. Arch. Gynecol. Obstet. 2014, 291, 319-325. [CrossRef] [PubMed]

5. Maiya, S.; Sullivan, I.; Allgrove, J.; Yates, R.; Malone, M.; Brain, C.; Archer, N.; Mok, Q.; Daubeney, P.; Tulloh, R.; et al. Hypocalcaemia and vitamin D deficiency: An important, but preventable, cause of life-threatening infant heart failure. Heart 2008, 94, 581-584. [CrossRef] [PubMed]

6. Mactier, H.; Weaver, L.T. Vitamin A and preterm infants: What we know, what we don't know, and what we need to know. Arch. Dis. Child. Fetal Neonatal Ed. 2005, 90, F103-F108. [CrossRef]

7. Strobel, M.; Tinz, J.; Biesalski, H.-K. The importance of $\beta$-carotene as a source of vitamin A with special regard to pregnant and breastfeeding women. Eur. J. Nutr. 2007, 46, 1-20. [CrossRef]

8. Grilo, E.C.; Medeiros, W.F.; Silva, A.G.A.; Gurgel, C.S.S.; Ramalho, H.M.M.; Dimenstein, R. Maternal supplementation with a megadose of vitamin A reduces colostrum level of $\alpha$-tocopherol: A randomised controlled trial. J. Hum. Nutr. Diet. 2016, 29, 652-661. [CrossRef]

9. DeLuca, H.F. Overview of general physiologic features and functions of vitamin D. Am. J. Clin. Nutr. 2004, 80, 1689S-1696S. [CrossRef]

10. Medeiros, D.M.; Wildman, R.E. Advanced Human Nutrition, 2nd ed.; Jones \& Bartlett Publishers: Burlington, MA, USA, 2013.

11. Cannell, J.J.; Hollis, B.W.; Zasloff, M.; Heaney, R.P. Diagnosis and treatment of vitamin D deficiency. Expert Opin. Pharmacother. 2007, 9, 107-118. [CrossRef]

12. Pettifor, J.M. Vitamin D deficiency and nutritional rickets in children. In Vitamin D, 3rd ed.; Elsevier: London, UK, 2011; pp. 1107-1128.

13. Kennedy, D.O. B Vitamins and the brain: Mechanisms, dose and efficacy-A Review. Nutrients 2016, 8, 68. [CrossRef] [PubMed]

14. Dror, D.K.; Allen, L.H. Vitamin b-12 in human milk: A systematic review. Adv. Nutr. 2018, 9, 358S-366S. [CrossRef] [PubMed]

15. Allen, L.H. B Vitamins in Breast Milk: Relative Importance of Maternal Status and Intake, and Effects on Infant Status and Function. Adv. Nutr. 2012, 3, 362-369. [CrossRef] [PubMed]

16. Depeint, F.; Bruce, W.R.; Shangari, N.; Mehta, R.; O’Brien, P.J. Mitochondrial function and toxicity: Role of the B vitamin family on mitochondrial energy metabolism. Chem. Biol. Interact. 2006, 163, 94-112. [CrossRef] [PubMed]

17. Sherry, C.L.; Oliver, J.S.; Renzi-Hammond, L.M.; Marriage, B.J. Lutein supplementation increases breast milk and plasma lutein concentrations in lactating women and infant plasma concentrations but does not affect other carotenoids. J. Nutr. 2014, 144, 1256-1263. [CrossRef] 
18. Vishwanathan, R.; Kuchan, M.J.; Sen, S.; Johnson, E.J. Lutein and preterm infants with decreased concentrations of brain carotenoids. J. Pediatr. Gastroenterol. Nutr. 2014, 59, 659-665. [CrossRef]

19. Hampel, D.; Shahab-Ferdows, S.; Adair, L.S.; Bentley, M.E.; Flax, V.L.; Jamieson, D.J.; Ellington, S.R.; Tegha, G.; Chasela, C.S.; Kamwendo, D.; et al. Thiamin and riboflavin in human milk: Effects of lipid-based nutrient supplementation and stage of lactation on vitamer secretion and contributions to total vitamin content. PLoS ONE 2016, 11, e0149479. [CrossRef]

20. Caulfield, L.E.; Richard, S.A.; Rivera, J.A.; Musgrove, P.; Black, R.E. Stunting, wasting, and micronutrient deficiency disorders. In Disease Control Priorities in Developing Countries, 2nd ed.; The International Bank for Reconstruction and Development/The World Bank; Oxford University Press: New York, NY, USA, 2006.

21. Kasalová, E.; Aufartová, J.; Krcmova, L.K.; Solichová, D.; Solich, P. Recent trends in the analysis of vitamin D and its metabolites in milk-A review. Food Chem. 2015, 171, 177-190. [CrossRef]

22. da Silva, A.L.C.; da Ribeiro, K.D.S.; de Melo, L.R.M.; Bezerra, D.F.; de Queiroz, J.L.C.; Lima, M.S.R.; Pires, J.F.; Bezerra, D.S.; Osório, M.M.; Dimenstein, R. Vitamin E in human milk and its relation to the nutritional requirement of the term newborn. Rev. Paul. Pediatr. 2017, 35, 158-164. [CrossRef]

23. Martysiak-Żurowska, D.; Szlagatys-Sidorkiewicz, A.; Zagierski, M. Concentrations of alpha- and gamma-tocopherols in human breast milk during the first months of lactation and in infant formulas. Matern. Child. Nutr. 2012, 9, 473-482. [CrossRef]

24. Ren, X.; Yang, Z.; Shao, B.; Yin, S.A.; Yang, X. B-vitamin levels in human milk among different lactation stages and areas in china. PLoS ONE 2015, 10, e0133285. [CrossRef] [PubMed]

25. Page, R.; Robichaud, A.; Arbuckle, T.E.; Fraser, W.D.; Macfarlane, A.J. Total folate and unmetabolized folic acid in the breast milk of a cross-section of Canadian women. Am. J. Clin. Nutr. 2017, 105, 1101-1109. [CrossRef] [PubMed]

26. Gentili, A.; Miccheli, A.; Tomai, P.; Baldassarre, M.E.; Curini, R.; Fernandez, V.P. Liquid chromatographytandem mass spectrometry method for the determination of vitamin $\mathrm{K}$ homologues in human milk after overnight cold saponification. J. Food Compos. Anal. 2016, 47, 21-30. [CrossRef]

27. Haug, M.; Laubach, C.; Burke, M.; Harzer, G. Vitamin e in human milk from mothers of preterm and term infants. J. Pediatr. Gastroenterol. Nutr. 1987, 6, 605-609. [CrossRef] [PubMed]

28. Hampel, D.; Shahab-Ferdows, S.; Islam, M.M.; Peerson, J.M.; Allen, L.H. Vitamin concentrations in human milk vary with time within feed, circadian rhythm, and single-dose supplementation. J. Nutr. 2017, 147, 603-611. [CrossRef]

29. Xu, C.Z.; Wang, H.F.; Yang, J.Y.; Wang, J.H.; Duan, Z.Y.; Wang, C.; Liu, J.X.; Lao, Y. Effects of feeding lutein on production performance, antioxidative status, and milk quality of high-yielding dairy cows. J. Dairy Sci. 2014, 97, 7144-7150. [CrossRef] [PubMed]

30. Jeon, S.; Ranard, K.M.; Neuringer, M.; Johnson, E.E.; Renner, L.; Kuchan, M.J.; Pereira, S.L.; Johnson, E.J.; Erdman, J.W., Jr. Lutein is differentially deposited across brain regions following formula or breast feeding of infant rhesus macaques. J. Nutr. 2018, 148, 31-39. [CrossRef] [PubMed]

31. Erdman, J.J.W., Jr.; Smith, J.; Kuchan, M.J.; Mohn, E.S.; Johnson, E.J.; Rubakhin, S.S.; Wang, L.; Sweedler, J.V.; Neuringer, M. Lutein and brain function. Foods 2015, 4, 547-564. [CrossRef]

32. Giampietri, M.; Lorenzoni, F.; Moscuzza, F.; Boldrini, A.; Ghirri, P. Lutein and neurodevelopment in preterm infants. Front. Neurosci. 2016, 10, 4034. [CrossRef]

33. Lipkie, T.E.; Morrow, A.L.; Jouni, Z.E.; McMahon, R.J.; Ferruzzi, M.G. Longitudinal survey of carotenoids in human milk from urban cohorts in China, Mexico, and the USA. PLoS ONE 2015, 10, e0127729. [CrossRef] [PubMed]

34. Cena, H.; Castellazzi, A.M.; Pietri, A.; Roggi, C.; Turconi, G. Lutein concentration in human milk during early lactation and its relationship with dietary lutein intake. Public Health Nutr. 2009, 12, 1878-1884. [CrossRef]

35. Sakurai, T.; Furukawa, M.; Asoh, M.; Kanno, T.; Kojima, T.; Yonekubo, A. Fat-soluble and water-soluble vitamin contents of breast milk from Japanese women. J. Nutr. Sci. Vitaminol. 2005, 51, 239-247. [CrossRef] [PubMed]

36. Xue, Y.; Redeuil, K.M.; Giménez, E.C.; Vinyes-Pares, G.; Zhao, A.; He, T.; Yang, X.; Zheng, Y.; Zhang, Y.; Wang, P.; et al. Regional, socioeconomic, and dietary factors influencing B-vitamins in human milk of urban Chinese lactating women at different lactation stages. BMC Nutr. 2017, 3, 1-11. [CrossRef] [PubMed] 
37. Duggan, C.P.; Srinivasan, K.; Thomas, T.; Samuel, T.; Rajendran, R.; Muthayya, S.; Finkelstein, J.L.; Lukose, A.; Fawzi, W.; Allen, L.H.; et al. Vitamin B-12 supplementation during pregnancy and early lactation increases maternal, breast milk, and infant measures of vitamin B-12 status. J. Nutr. 2014, 144, 758-764. [CrossRef] [PubMed]

38. Kamao, M.; Tsugawa, N.; Suhara, Y.; Wada, A.; Mori, T.; Murata, K.; Nishino, R.; Ukita, T.; Uenishi, K.; Tanaka, K.; et al. Quantification of fat-soluble vitamins in human breast milk by liquid chromatography-tandem mass spectrometry. J. Chromatogr. B 2007, 859, 192-200. [CrossRef]

39. Kim, H.; Jung, B.-M.; Lee, B.-N.; Kim, Y.-J.; Jung, J.A.; Chang, N. Retinol, $\alpha$-tocopherol, and selected minerals in breast milk of lactating women with full-term infants in South Korea. Nutr. Res. Pr. 2017, 11, 64-69. [CrossRef]

40. De Lira, L.Q.; Lima, M.S.R.; De Medeiros, J.M.S.; Da Silva, I.F.; Dimenstein, R. Correlation of vitamin A nutritional status on alpha-tocopherol in the colostrum of lactating women. Matern. Child. Nutr. 2011, 9, 31-40. [CrossRef]

41. Mello-Neto, J.; Rondo, P.H.C.; Oshiiwa, M.; Morgano, M.A.; Zacari, C.Z.; Domingues, S. The influence of maternal factors on the concentration of vitamin A in mature breast milk. Clin. Nutr. 2009, 28, 178-181. [CrossRef]

42. Oberhelman, S.S.; Meekins, M.E.; Fischer, P.R.; Lee, B.R.; Singh, R.J.; Cha, S.S.; Gardner, B.M.; Pettifor, J.M.; Croghan, I.T.; Thacher, T.D. Maternal vitamin D supplementation to improve the vitamin D status of breast-fed infants: A randomized controlled trial. Mayo Clin. Proc. 2013, 88, 1378-1387. [CrossRef]

43. Streym, S.; Højskov, C.S.; Møller, U.K.; Heickendorff, L.; Vestergaard, P.; Mosekilde, L.; Rejnmark, L. Vitamin D content in human breast milk: A 9-mo follow-up study. Am. J. Clin. Nutr. 2015, 103, 107-114. [CrossRef]

44. Kojima, T.; Asoh, M.; Yamawaki, N.; Kanno, T.; Hasegawa, H.; Yonekubo, A. Vitamin K concentrations in the maternal milk of Japanese women. Acta Paediatr. 2004, 93, 457-463.

45. Greer, F.R. Are breast-fed infants vitamin K deficient? In Bioactive Components of Human Milk; Springer: New York, NY, USA, 2001; pp. 391-395.

46. Haroon, Y.; Shearer, M.J.; Rahim, S.; Gunn, W.G.; McEnery, G.; Barkhan, P. The content of phylloquinone (vitamin k1) in human milk, cows' milk and infant formula foods determined by high-performance liquid chromatography. J. Nutr. 1982, 112, 1105-1117. [CrossRef] [PubMed]

47. Canfield, L.M.; Hopkinson, J.M.; Lima, A.F.; Silva, B.; Garza, C. Vitamin K in colostrum and mature human milk over the lactation period-a cross-sectional study. Am. J. Clin. Nutr. 1991, 53, 730-735. [CrossRef] [PubMed]

48. Greer, F.R.; Marshall, S.; Cherry, J.; Suttie, J.W. Vitamin K status of lactating mothers, human milk, and breast-feeding infants. Pediatrics 1991, 88, 751-756. [PubMed]

49. Jackson, J.G.; Zimmer, J.P. Lutein and zeaxanthin in human milk independently and significantly differ among women from Japan, Mexico, and the United Kingdom. Nutr. Res. 2007, 27, 449-453. [CrossRef]

50. Xue, Y.; Giménez, E.C.; Redeuil, K.M.; Lévèques, A.; Actis-Goretta, L.; Vinyes-Pares, G.; Zhang, Y.; Wang, P.; Thakkar, S.K. Concentrations of carotenoids and tocopherols in breast milk from urban chinese mothers and their associations with maternal characteristics: A cross-sectional study. Nutrients 2017, 9, 1229. [CrossRef] [PubMed]

51. Food and Agriculture Organization/World Health Organization. Vitamin and Mineral Requirements in Human Nutrition, 2nd ed.; World Health Organization: Rome, Italy, 2005.

52. Hollis, B.W.; Wagner, C.L. Vitamin D requirements during lactation: High-dose maternal supplementation as therapy to prevent hypovitaminosis D for both the mother and the nursing infant. Am. J. Clin. Nutr. 2004, 80, 1752S-1758S. [CrossRef]

53. Ziegler, E.E.; Nelson, S.E.; Jeter, J.M. Vitamin D supplementation of breastfed infants: A randomized dose-response trial. Pediatr. Res. 2014, 76, 177-183. [CrossRef]

(C) 2020 by the authors. Licensee MDPI, Basel, Switzerland. This article is an open access article distributed under the terms and conditions of the Creative Commons Attribution (CC BY) license (http://creativecommons.org/licenses/by/4.0/). 